\title{
Winds of change blowing hard in British science museums
}

\section{London}

DECLINING support from the government is forcing Britain's science museums to think hard about ways of reducing costs and attracting funds from alternative sources.

The government is loosening its hold over the museums in an effort to encourage them to forge closer partnerships with the private sector. The British Museum (Natural History), BM(NH), was until a month ago under the aegis of the Department of Education and Science, receiving its funds ( $£ 11.44$ million last year) from the science budget. On 1

$A$ wedding reception among the dinosaurs now possible at $B M(N H)$.

August, $\mathrm{BM}(\mathrm{NH})$ was brought into line with the other main museums and passed over to the Office of Arts and Libraries.

On 1 April, funding arrangements for $\mathrm{BM}(\mathrm{NH})$ and its neighbour, the Science Museum, were changed, with the government money coming as grant-in-aid, releasing the museums from many of the Treasury's annuality restraints.

Furthermore, the government is shortly to hand over the responsibility for the museums' buildings and estates from the government's Property Services Agency to the museums' trustees. The sums are not inconsiderable - in 1985-86 PSA was given $£ 4.8$ million to spend on $\mathrm{BM}(\mathrm{NH})$.

At the Science Museum, the new director, Neil Cossons, appointed 18 months ago, is making his presence felt. He hopes to bring the four curatorial departments under the single roof of a 'collections management' department. Research priorities will be redefined by a new head of research, with responsibility for the library service, and a separate marketing division is to be created.
Last year, the Science Museum received $£ 8.8$ million from the government, with earnings from publishing, retailing and hiring of rooms totalling $£ 879,000$. Sponsorship from industry netted almost $£ 1$ million. Cossons believes there is much scope for increasing earnings from nongovernment sources. But many of the museum's curators are suspicious. Cossons' pledge that he has "no intention" of introducing compulsory redundancies is not regarded as a sufficiently strong guarantee of job security. Several members of staff have been refusing to cooperate with external management consultants brought in to find the best way of implementing the changes.

So far, Cossons has refrained from recommending the introduction of admission fees to the museum's public galleries. $\mathrm{He}$ is, however, keeping a close eye on $\mathrm{BM}(\mathrm{NH})$ next door, which started charging visitors on 1 April this year, and whose attendance trends traditionally closely reflect those of the Science Museum.

$\mathrm{BM}(\mathrm{NH})$ says that it is too soon to gauge the effect of the charges, although admissions do not seem to have changed significantly so far. $\mathrm{BM}(\mathrm{NH})$ is pinning its hopes on the success of the new charging policy which is calculated to generate $£ 1.6$ million annually by $1990-91$. The first formal appraisal of the effect of admission fees is due towards the end of this year. The museum could find difficulty in convincing opponents of the new policy that an estimated 20 per cent drop in attendance figures was expected simply by virtue of the inaccuracy of assessing the numbers of visitors before charging was introduced.

Because curation and research swallow by far the largest proportion of BM(NH)'s resources (41 per cent in 1985-86), the museum's management is trying to lessen the financial burden they impose. If further manpower cuts are necessary, the scientific staff will bear the brunt. The management is also considering ways of marketing the abundance of scientific expertise.

Like the Science Museum, $\mathrm{BM}(\mathrm{NH})$ is embarking on a fierce marketing programme. With industrial sponsorship unlikely to be a big money-spinner, most efforts are being concentrated on giving the museum a higher public profile, aimed at pulling more paying customers through the turnstiles. Renting rooms for parties, something that has attracted the attention of the national media, represents a further, small source of income.

When BM(NH)'s new director, Neil Chalmers, replaces Ronald Hedley next year, he will be taking charge of a muchchanged institution. Simon Hadlington

\section{Academic networks} Taking stock

\section{Munich}

STILL in its infancy, the European Academic and Research Network (EARN), a computer communications network, is now embarking on enforced independence without the comforting support of computer giant IBM. EARN must learn to live with the potentially disastrous tariff policies of some European telecommunications monopolies, earning at least enough income to replace the $\$ 15$ million provided by IBM over the past four years. But director Dennis Jennings is confident that EARN will stay the course.

Since 1984, EARN has connected more than 2,000 computers in 20 countries, largely with the help of IBM's determination to overcome wildly different standards and attitudes in the host countries. The network now includes Israel, the Ivory Coast and Iceland. All members are also connected to US research institutions through BITNET, a US computer network.

EARN's success is measured by its growth. In West Germany, for example, EARN traffic has doubled every 10 months since the beginning. The West German data lines, which carried 2,400 bits per second (b.p.s.) at the outset, have been largely replaced by lines carrying 9,600 b.p.s. and may soon be upgraded to 64,000 b.p.s., already available in many other European countries.

But who will pay the costs when IBM support runs out at the end of 1987 ? EARN directors decided at Nice in May to adopt the "BITNET model" to fund the lines connecting the various countries. Under that scheme, each user pays for the line leading to its neighbour; the members share the cost of one line to the United States and the other line is paid for by West Germany.

Because of huge discrepancies in the cost of the international lines, however, several countries are considering shifting their lines out of high-priced areas such as West Germany (see opposite) and Switzerland. The United Kingdom, for example, is contemplating a shift of its lines from Geneva to Montpélier, France. West Germany may lose all but one of its five international data lines because its charges are so high. These shifts are not expected to hurt EARN's performance.

Nor do most countries expect difficulty with the transition to self-management. Networks such as SWITCH in Switzerland, JANET in Britain, SURF in Holland and REUNIR in France will continue to belong to EARN. The only problem will be convincing funding bodies to give support to the network. But EARN director Dennis Jennings is confident that all countries have established a 